\title{
Dry matter and nitrogen accumulation and seed yield in determinate autumn-sown white lupins (Lupinus albus L)
}

\author{
B Julier*, C Huyghe, J Papineau \\ with the technical assistance of JM Pissard and P Cormenier
}

INRA, Station d'Amélioration des Plantes Fourragères, F86600 Lusignan, France

(Received 16 July 1993; accepted 26 October 1993)

\begin{abstract}
Summary - Determinate autumn-sown white lupins (Lupinus albus $\mathrm{L}$ ) are new types which are potentially interesting for the improvement of yield stability and for cultivation of lupins in northern Europe. Two determinate genotypes were studied in 1990/1991 and 1991/1992 at Lusignan, France, under 17 combinations of sowing date, density and irrigation. Dry matter production was $1061 \mathrm{~g} / \mathrm{m}^{2}$ on average and the duration of the growing cycle was $2284^{\circ} \mathrm{C} \cdot \mathrm{d}$ (degree•day) from sowing (base $3^{\circ} \mathrm{C}$ ). Late sowing date and low density induced a reduction of total biomass at maturity. The leaf area index (LAl) was 2.6 on average at its maximum and the mainstem was the level with the highest LAI, followed by the first-order branches and the second-order branches. Mean seed yield was $3.65 \mathrm{tha}$, and was rather stable over the agronomic conditions. Yield was correlated with total above-ground matter, but was independent of harvest index. Yield was also correlated with number of seeds per $\mathrm{m}^{2}$ but was independent of mean seed weight. Yield on the mainstem was, statistically, totally explained by the number of mainstem leaves per $\mathrm{m}^{2}$. Relationships between the yields of the different pod orders were detected. Nitrogen accumulation followed dry matter accumulation, and the mean nitrogen harvest index was 0.82 . All the results were compared with those obtained on the indeterminate, autumn-sown cultivar Lunoble.
\end{abstract}

lupin / determinate architecture / growth / yield / assimilate partitioning

Résumé - Accumulation de la matière sèche et de l'azote, et rendement en graines des lupins d'hiver déterminés (Lupinus albus L). Les lupins d'hiver à architecture déterminée sont potentiellement intéressants pour augmenter la stabilité du rendement et étendre la zone de culture du lupin d'hiver au nord de l'Europe. Deux génotypes déterminés ont été étudiés en 1990/1991 et 1991/1992 à Lusignan (France) dans 17 combinaisons de dates de semis, de densités et d'irrigation. La production de matière sèche moyenne est de $1060 \mathrm{~g} / \mathrm{m}^{2}$ et la durée du cycle de végétation de $2284^{\circ} \mathrm{C} \cdot \mathrm{J}$ depuis le semis (base $3^{\circ} \mathrm{C}$ ). Des dates de semis tardives ou des densités faibles diminuent la production de biomasse. L'indice foliaire (IF) était de 2,6 à son maximum en moyenne, la tige principale ayant le plus fort IF, suivie des ramifications primaires puis des ramifications secondaires. Le rendement moyen en grain est de 3,65 tha, et il est relativement stable vis-à-vis des conditions agronomiques. Le rendement est corrélé à la production de biomasse, mais indépendant de l'indice de récolte. Les lupins déterminés dans la gamme de conditions étudiées ici ont un indice de récolte élevé et stable, mais c'est la production en biomasse qui conditionne le niveau de rendement. Le rendement est aussi corrélé au nombre de graines par $\mathrm{m}^{2}$ mais indépendant du poids moyen d'une graine. La mise en place des gousses est pratiquement simultanée sur la tige principale et les ramifications, ce qui pourrait être à l'origine d'un manque transitoire d'assimilats pendant la nouaison, conduisant à une restriction du nombre de graines ou de gousses. En revanche, le remplissage des graines n'est pas un facteur limitant du rendement. Au niveau statistique, le rendement sur la tige principale est entièrement expliqué par le nombre de feuilles sur la tige principale par $\mathrm{m}^{2}$. II existe des relations entre les rendements des différents niveaux. L'accumulation de l'azote est parallèle à l'accumulation de la matière sèche, et l'indice de récolte de l'azote dans les graines est de 0,82. Tous ces résultats sont comparés à ceux obtenus sur la variété indéterminée Lunoble utilisée comme témoin dans cette étude.

* Correspondence and reprints 


\section{INTRODUCTION}

Sowing white lupin (Lupinus albus $L$ ) in autumn is a common agricultural practice in southern European countries. However, the first cultivars with high levels of frost tolerance were released only recently. Their seed yield potential is high (Huyghe et al, 1993) but their yield stability remains poor because of excessive vegetative development in wet conditions and the simultaneous growth of vegetative and reproductive parts. On other legume crops, attempts to reduce vegetative growth were made either by modification of leaf characters as in pea (Snoad, 1974) or by introduction of the determinate growth habit as in field bean (Sjödin, 1971) and soybean (Bernard, 1972). Breeding autumn-sown lupins has focused on 2 new architectural types, determinate and dwarf (Huyghe, 1990). The determinate character was shown to be monogenic recessive (Julier and Huyghe, 1992). The comparison of a determinate line and an indeterminate line in a large range of environments in France and the UK (Julier et al, 1993b) has shown similar mean seed yields but the seed yield stability was clearly improved in the determinate line. Maturity time of the determinate line was slightly earlier in France, and significantly so in the cool, wet climate of the UK. This new architecture offers prospects for expanding production of autumnsown white lupin further north in Europe, in cool and wet areas (Julier et al, 1993b) and confirms the assumptions obtained by Milford et al (1993b) after pruning experiments on indeterminate genotypes.

The study of the late-flowering, indeterminate cultivar Lunoble by Huyghe et al (1993) and Julier et al (1993a) showed that it produced $1500 \mathrm{~g} /$ $\mathrm{m}^{2}$ of above-ground dry matter with the major part stored in the mainstem and branches. Each branch level developed numerous leaves so that, at the density of 10 or 20 plants $/ \mathrm{m}^{2}$, each level reached a leaf area index (LAl) of 2 and the maximum LAl of the whole canopy was 5.5 . The seed yield depended similarly on the number of seeds per $\mathrm{m}^{2}$ and the mean seed weight. There was a negative relationship between the seed yield on the mainstem and the weight of the branches, showing competition for assimilates between the pods and the vegetative plant parts.

The determinate growth habit has already been studied in spring-sown white lupin (Mikolajczyk et al, 1984). With spring lupins, determinate architecture presented little interest be- cause of the extreme reduction of its vegetative growth. But the vegetative development of lateflowering determinate autumn-sown genotypes is not so reduced, and at least 1 branch order is produced (Julier and Huyghe, 1993). The reduction of vegetative development in determinate types compared with indeterminates allows us to assume that within-plant competition between vegetative and reproductive growths will be lessened. Dry matter accumulation in the various parts of determinate lupin plants, according to growing conditions (season, sowing date and plant density), is described in this paper. The influence of these growing conditions on seed yield, in relation to dry matter production, will be tested. The results will be compared with those previously obtained on the indeterminate autumn-sown cv Lunoble by Huyghe et al (1993) and Julier et al (1993a).

\section{MATERIAL AND METHODS}

Two closely related determinate genotypes, $\mathrm{CH} 304 / 70$ and $\mathrm{CH} 304 / 73$, originating from the same cross, were studied. Both of them are late-flowering lines but $\mathrm{CH} 304 / 73$ flowers earlier than $\mathrm{CH} 304 / 70$. Field trials were conducted at INRA, Lusignan, France, in a deep clay silt soil at $\mathrm{pH} 6.7$, with an available soil water content at field capacity of $100 \mathrm{~mm}$ within the rooting zone.

Experiment 1 involved $\mathrm{CH} 304 / 70$ in 1990/1991 and both $\mathrm{CH} 304 / 70$ and $\mathrm{CH} 304 / 73$ in 1991/1992. Sowings were performed on 2 dates, on $05 / 10$ and 22/10 in 1990 , and on $05 / 10$ and $25 / 10$ in 1991. For each sowing date, 2 plant densities were used, 13 and 20 plants $/ \mathrm{m}^{2}$ in $1990 / 1991$ and 10 and 20 plants $/ \mathrm{m}^{2}$ in 1991/1992. The densities were obtained by handthinning plots at the beginning of March. The experiment was in a randomized block design with 3 replications, and also included the indeterminate $\mathrm{cv}$ Lunoble as a control. Lunoble is one of the highest yielding autumn-sown cultivars currently available. Each year, plots were irrigated as needed until the beginning of July to avoid plant wilting. In 1990/1991 and 1991/ 1992,73 and $80 \mathrm{~mm}$ of water were added respectively during the late spring (see Julier et al, 1993a). The plot size was $7 \times 7.2 \mathrm{~m}$ with 12 rows, $0.6 \mathrm{~m}$ apart. During the growing season, 8 samplings of $1 \mathrm{~m}^{2}$ each were made, starting at the beginning of stem elongation and ending at maturity. Each sampling was separated from the following by 1 edge row. Plants were separated into tap-root, and per inflorescence level, into stems, leaves and pods. Basal branches were also separated. Dry weights were obtained after ovendrying at $80^{\circ} \mathrm{C}$ for $36 \mathrm{~h}$. Maximum growth rate was calculated as the slope of dry matter against thermal time during the linear growth period, for the curves of total and pod dry matter. The duration of the linear growth 
period was empirically determined on the graphs and will be presented with the values of the slopes. Nitrogen content in each plant part was estimated by the Kjeldahl method using an Auto-Analyzer ${ }^{R}$ II, Technicon $^{R}$. Sampling dates were transformed into sums of degree day $\left({ }^{\circ} \mathrm{C} \cdot \mathrm{d}\right.$ ) above $3^{\circ} \mathrm{C}$ from sowing (Huyghe, 1991). Specific leaf weight, calculated as the mass of leaf tissue per unit leaf area, was estimated for each genotype on the second, third and fourth samplings. Three and 6 plants at low and high densities, respectively, were taken to determine leaf area with a planimeter (Delta-T Devices ${ }^{R}$ ) and leaf dry weight per level. The leaf weight per $\mathrm{m}^{2}$ of soil in each sampling was transformed into LAl through the specific leaf weight. Plant morphology was described by the mean of 30 plants for the number of mainstem leaves, the number of leaves on the first-order branches, and the number of first-order branches. In this paper, $\mathrm{AO}$ will refer to the mainstem, A1 to first-order branches, A2 to second-order branches (Farrington and Greenwood, 1975). Seed yield and mean seed weight per level were estimated at the last sampling.

In experiment 2, $\mathrm{CH} 304 / 70$ and $\mathrm{CH} 304 / 73$ were sown at 3 dates in $1991(18 / 09,05 / 10$ and 25/10) and 3 densities each $\left(10,20,40\right.$ plants per $\left.\mathrm{m}^{2}\right)$. Rows were $0.6 \mathrm{~m}$ apart for the 2 lowest densities and $0.3 \mathrm{~m}$ apart for the highest. The design had 3 replications, and included the cv Lunoble as a control. This experiment was not irrigated. The yield was measured on a plot of $3 \times 1.2 \mathrm{~m}$. On a subplot of $3 \times 0.6 \mathrm{~m}$, plants were separated at maturity into stems, and per level into seeds and pod walls, and weighed. Seed number was counted to calculate mean seed weight. Plant morphology was recorded as previously described.
Experiments 1 and 2 were combined for the analysis of variance of yield, number of seeds per $\mathrm{m}^{2}$, mean seed weight and harvest index.

\section{RESULTS AND DISCUSSION}

\section{Influence of climate on architecture}

Winter weather was colder during 1991/1992 than during 1990/1991 resulting in a lower number of leaves on the mainstem in 1991/1992 (table I) as modelled by Huyghe (1991). Each year, delayed sowing reduced the number of mainstem leaves. The number of leaves on firstorder branches and number of first-order branches were strongly associated with the number of mainstem leaves and only slightly decreased at the highest density (Julier and Huyghe, 1993). The early-flowering line $\mathrm{CH} 304 /$ 73 carried fewer leaves on each level than $\mathrm{CH} 304 / 70$. Spring and summer 1991 were hot and dry. Spring 1992 was dry, and summer 1992 rather wet (Julier et al, 1993a). Irrigation had no significant influence on the architecture of the mainstem and first-order branches (table I); this architecture was defined very early in the season at a time when no water stress had occurred.

Table I. Leaf number on the mainstem and first-order branches, for 2 determinate genotypes (CH304/70 and $\mathrm{CH} 304 /$ 73) grown in 1990/1991 and 1991/1992 at 3 sowing dates and 3 plant densities (10 or 13, 20 and 40 plants/m²) at Lusignan, France, with (irrig) or without irrigation (un-irrig).

\begin{tabular}{|c|c|c|c|c|c|c|c|}
\hline \multirow[t]{3}{*}{ Sowing date } & \multirow{3}{*}{$\begin{array}{c}\text { Number of } \\
\text { mainstem leaves }\end{array}$} & \multicolumn{6}{|c|}{ Number of leaves on first-order branches } \\
\hline & & \multicolumn{2}{|c|}{$13 / 10$ plants $/ \mathrm{m}^{2}$} & \multicolumn{2}{|c|}{20 plants $/ m^{2}$} & \multicolumn{2}{|c|}{40 plants $/ m^{2}$} \\
\hline & & irrig & un-irrig & irrig & un-irrig & irrig & un-irrig \\
\hline \multicolumn{8}{|c|}{ 1990/1991 CH304/70 } \\
\hline $05 / 10$ & 31.5 & 22.9 & - & 23.6 & - & - & - \\
\hline $22 / 10$ & 28.8 & 15.3 & - & 13.4 & - & - & - \\
\hline \multicolumn{8}{|c|}{ 1991/1992 CH304/70 } \\
\hline $18 / 09$ & 42.3 & - & 30.3 & - & 21.7 & - & 22.9 \\
\hline $05 / 10$ & 28.7 & 17.5 & 14.6 & 13.3 & 13.2 & - & 10.7 \\
\hline $25 / 10$ & 22.8 & 16.9 & 16.6 & 15.0 & 15.1 & - & 12.7 \\
\hline \multicolumn{8}{|c|}{ 1991/1992 CH304/73 } \\
\hline $18 / 09$ & 33.1 & - & 34.0 & - & 31.8 & - & 22.3 \\
\hline $05 / 10$ & 23.9 & 13.0 & 12.1 & 11.8 & 11.7 & - & 8.3 \\
\hline $25 / 10$ & 18.7 & 10.1 & 8.8 & 9.4 & 9.0 & - & 8.0 \\
\hline
\end{tabular}




\section{Growth and development (experiment 1)}

\section{Total dry matter}

Accumulation of total dry matter during the growing season followed the same general sigmoid curve for each genotype, sowing date and density (fig 1). The linear growth period started at flowering of the mainstem (between 980 and $1090^{\circ} \mathrm{C} \cdot d$ from sowing depending on the genotypes and the conditions) for the low density and before flowering for the high density. The curves were different for the slope of the linear growth period, the maximum dry weight and the duration of the season (table II). Delaying sowing date had little influence on maturity date, so the duration of the growing season expressed in ${ }^{\circ} \mathrm{C} \cdot \mathrm{d}$ was reduced. Maturity occurred on average at 2352 and $2216{ }^{\circ} \mathrm{C} \cdot \mathrm{d}$ for the first and second sowings respectively. This thermal time requirement allows us to estimate if $\mathrm{CH} 304 / 70$ or $\mathrm{CH} 304 / 73$ can be cultivated in different regions, considering their long-term average temperatures. These 2 determinate genotypes matured earlier than Lunoble $\left(2352^{\circ} \mathrm{C} \cdot \mathrm{d}\right.$ for determinates and $2600^{\circ} \mathrm{C} \cdot \mathrm{d}$ for Lunoble when sown in earlyOctober). This can allow the extension of autumn-sown white lupin in northern Europe, under cool and wet climates. Successful maturation was actually observed in Rothamsted (UK) in 1990/1991 (Julier et al, 1993b).

The maximum dry matter tended to decrease with low density and late sowing date (table II).

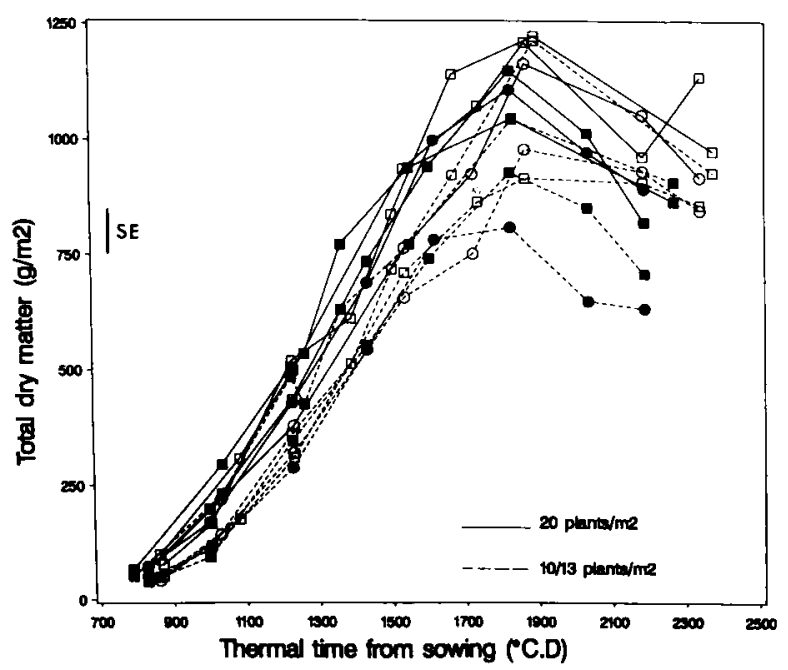

Fig 1. Total dry matter accumulation for 2 determinate genotypes ( $\square$, n: $\mathrm{CH} 304 / 70$ and $\mathrm{O}, 0$ : $\mathrm{CH} 307 / 73)$ in 1990/1991 and 1991/1992, sown at 2 dates (O,D: early sowing, late sowing) with 2 densities.
Maximum dry matter was $1118 \mathrm{~g} / \mathrm{m}^{2}$ on average for the early sowing and $1014 \mathrm{~g} / \mathrm{m}^{2}$ for the late sowing. Final dry matter mainly results from a combination of the duration of the growing season and the maximum growth rate. The late sowing reduced both the duration of the growing season and the maximum growth rate in 1990/1991, and only the duration of the growing season in $1991 / 1992$. The low plant density significantly reduced the dry matter only in 1991/1992 and this was related to lower maximum growth rates. Compared with Lunoble, the dry matter production of determinate genotypes was strongly reduced (on average 1118 versus $1506 \mathrm{~g} / \mathrm{m}^{2}$ in the early-October sowing). This was the consequence of a shorter growing season associated with a lower overall growth rate (1.05 and 1.34

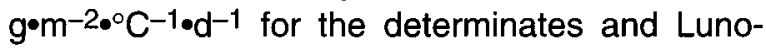
ble, respectively, when sown in early-October).

At maximum dry matter stage (table III), level A0 represented the heaviest part of the plants, between 48 and $66 \%$ of the total dry matter; $A 1$ accounted for 24 to $37 \%$; and $\mathrm{A} 2$ represented only between 4 and $15 \%$ of total weight, and was more important for $\mathrm{CH} 304 / 73$ than for $\mathrm{CH} 304 / 70$. At the lower density, $A 0$ was reduced, $A 2$ was increased, and $A 1$ was increased only in 1990/ 1991. Late sowing reduced dry matter on $A 0$ in relation with the reduction of number of mainstem leaves. While the weight of $A O$ was similar for determinates than for Lunoble (Julier et al, 1993a), A1 and A2 were less developed on determinates than on Lunoble as a consequence of the modification of the structure of the first-order branches (Julier and Huyghe, 1993). Some basal branches developed and always weighed less than $\mathrm{A} 2$.

\section{Leaf dry weight}

Mean specific leaf weight was similar for $\mathrm{CH} 304 /$ 70 and $\mathrm{CH} 304 / 73$ : $59.5 \pm 0.3 \mathrm{~g} / \mathrm{m}^{2}$ of leaves. Leaf dry matter was transformed into LAl using this coefficient (fig 2). LAl increased rapidly during spring, then reached a maximum and declined to 0 . At maturity, all the leaves had fallen. Maximum LAl averaged 2.64 but varied between 1.84 and 3.50 depending on the season, sowing date and density. LAl was greater in 1990/1991 than in 1991/1992, at high density than at low density, and under an early sowing date than under a late sowing date. An LAl of 2.5 which allows $90 \%$ interception of incident radiation (Huyghe, 1992) was not reached by the 4 low- 


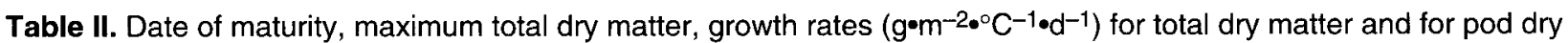
matter during the linear growing period (duration of this period in brackets), and pod dry matter at maturity for 2 determinate genotypes $(\mathrm{CH} 304 / 70$ and $\mathrm{CH} 304 / 73)$ grown in 1990/1991 and 1991/1992 at 2 sowing dates and 2 plant densities at Lusignan.

\section{Sowing Plant Maturity Maturitydate Maximum total Totalgrowth Poddrymatter Podgrowth rate} date density date $\left({ }^{\circ} \mathrm{C} \bullet d\right)$ drymatter $\left(g / \mathrm{m}^{2}\right)$ rate (duration) at maturity $\left(\mathrm{g} / \mathrm{m}^{2}\right)$ (duration)

\begin{tabular}{|c|c|c|c|c|c|c|c|c|c|}
\hline \multicolumn{10}{|c|}{ 1990/1991 CH304/70 } \\
\hline $05 / 10$ & 13 & $07 / 08$ & 2376 & 1214 & 1.166 & $\left(\begin{array}{ll}1 & 021\end{array}\right)$ & 554 & 1.144 & $(503)$ \\
\hline $05 / 10$ & 20 & $"$ & $"$ & 1224 & 1.214 & (1 021) & 549 & 1.120 & (503) \\
\hline $22 / 10$ & 13 & $13 / 08$ & 2270 & 1044 & 0.976 & (1 042) & 577 & 0.962 & (605) \\
\hline $22 / 10$ & 20 & $"$ & $"$ & 1045 & 1.011 & (1 042) & 542 & 0.939 & $(605)$ \\
\hline \multicolumn{10}{|c|}{ 1991/1992 CH304/70 } \\
\hline $05 / 10$ & 10 & $05 / 08$ & 2340 & 916 & 0.943 & $\left(\begin{array}{lll}1 & 003\end{array}\right)$ & 602 & 0.875 & $(633)$ \\
\hline $05 / 10$ & 20 & $"$ & $"$ & 1210 & 1.143 & $(1003)$ & 741 & 1.038 & (633) \\
\hline $25 / 10$ & 10 & $04 / 08$ & 2189 & 928 & 0.943 & (996) & 518 & 0.911 & (595) \\
\hline $25 / 10$ & 20 & $"$ & $"$ & 1149 & 1.134 & (996) & 604 & 1.114 & (595) \\
\hline \multicolumn{10}{|c|}{ 1991/1992 CH304/73 } \\
\hline $05 / 10$ & 10 & $05 / 08$ & 2340 & 978 & 0.925 & $(1003)$ & 628 & 0.884 & (633) \\
\hline $05 / 10$ & 20 & $"$ & $"$ & 1164 & 1.065 & $(1003)$ & 662 & 1.053 & (633) \\
\hline $25 / 10$ & 10 & $04 / 08$ & 2189 & 809 & 0.942 & (996) & 465 & 1.037 & (595) \\
\hline $25 / 10$ & 20 & $"$ & $"$ & 1108 & 1.124 & $(789)$ & 684 & 1.098 & (389) \\
\hline \multicolumn{3}{|c|}{ Mean } & 2284 & 1061 & \multicolumn{2}{|l|}{1.049} & 594 & \multicolumn{2}{|l|}{1.015} \\
\hline \multicolumn{3}{|c|}{ LSD genotype } & 0 & 94.8 & \multicolumn{2}{|l|}{0.0727} & 101.2 & \multicolumn{2}{|l|}{0.0977} \\
\hline \multicolumn{3}{|c|}{ LSD sowing date } & 18.8 & 89.3 & \multirow{2}{*}{\multicolumn{2}{|c|}{$\begin{array}{l}0.1260 \\
0.0702\end{array}$}} & 97.7 & \multicolumn{2}{|l|}{0.0944} \\
\hline \multicolumn{3}{|c|}{ LSD density } & 0 & 89.3 & & & 87.6 & 0.1597 & \\
\hline
\end{tabular}

CH30470

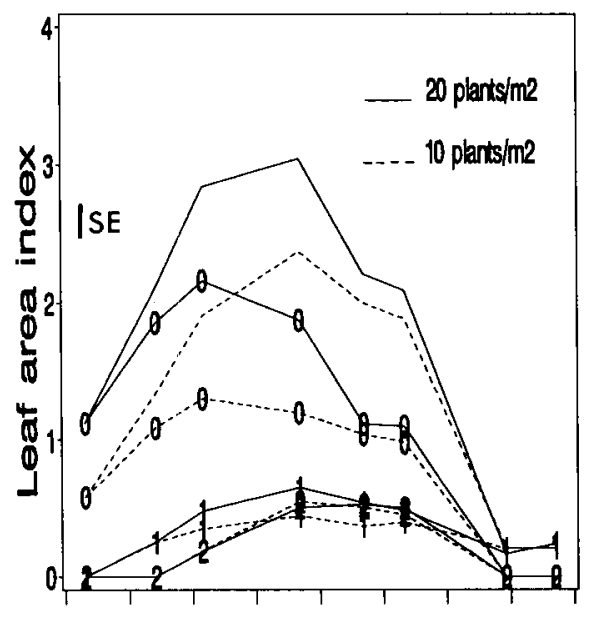

$800 \quad 10001200140016001800200022002400$

Thermal time from sowing ( ${ }^{\circ}$.D.D)
CH304/73

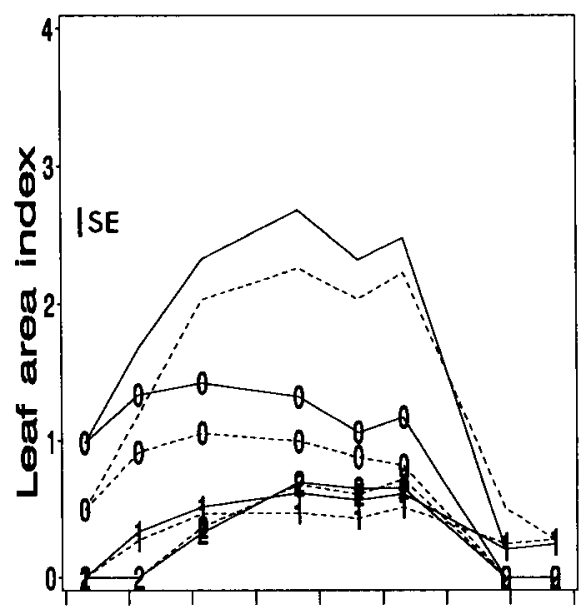

$800 \quad 1000 \quad 1200 \quad 1400 \quad 1600 \quad 1800 \quad 2000 \quad 2200 \quad 2400$

Thermal time from sowing ( $\left.{ }^{\circ} \mathrm{C} . \mathrm{D}\right)$

Fig 2. Leaf area index per level (0: A0; $1: A 1 ; 2: A 2)$ and total leaf area index (lines without symbols) for 2 determinate genotypes (CH304/70 and $\mathrm{CH} 304 / 73$ ) in 1991/1992, sown on 05/10 with 2 densities. Leaves on basal branches were omitted. SE are for the total leaf area index curves. 
Table III. Dry matter $\left(\mathrm{g} / \mathrm{m}^{2}\right)$ per level at maximum dry matter stage, for 2 determinate genotypes $(\mathrm{CH} 304 / 70$ and $\mathrm{CH} 304 / 73$ ) grown in 1990/1991 and 1991/1992 at 2 sowing dates and 2 plant densities at Lusignan.

\begin{tabular}{|c|c|c|c|c|c|}
\hline $\begin{array}{l}\text { Sowing } \\
\text { date }\end{array}$ & $\begin{array}{c}\text { Plant } \\
\text { density }\end{array}$ & $\begin{array}{c}\text { Basal } \\
\text { branches }\end{array}$ & $A O$ & $A 1$ & $A 2$ \\
\hline \multicolumn{6}{|c|}{ 1990/1991 CH304/70 } \\
\hline $05 / 10$ & 13 & - & 725 & 347 & 68 \\
\hline $05 / 10$ & 20 & - & 808 & 295 & 43 \\
\hline $22 / 10$ & 13 & - & 602 & 320 & 54 \\
\hline $22 / 10$ & 20 & - & 672 & 265 & 31 \\
\hline \multicolumn{6}{|c|}{ 1991/1992 CH304/70 } \\
\hline $05 / 10$ & 10 & 17 & 546 & 246 & 60 \\
\hline $05 / 10$ & 20 & 0 & 798 & 278 & 63 \\
\hline $25 / 10$ & 10 & 13 & 442 & 345 & 80 \\
\hline $25 / 10$ & 20 & 0 & 682 & 351 & 53 \\
\hline \multicolumn{6}{|c|}{ 1991/1992 CH304/73 } \\
\hline $05 / 10$ & 10 & 45 & 429 & 311 & 147 \\
\hline $05 / 10$ & 20 & 9 & 671 & 315 & 106 \\
\hline $25 / 10$ & 10 & 49 & 347 & 256 & 120 \\
\hline $25 / 10$ & 20 & 10 & 605 & 347 & 96 \\
\hline \multicolumn{2}{|l|}{ Mean } & 12 & 611 & 306 & 76 \\
\hline \multicolumn{2}{|c|}{ LSD genotype } & 8.6 & 49.0 & 42.6 & 15.3 \\
\hline \multicolumn{2}{|c|}{ LSD sowing date } & 8.1 & 46.2 & 40.2 & 14.4 \\
\hline \multicolumn{2}{|c|}{ LSD density } & 8.1 & 46.2 & 40.2 & 14.4 \\
\hline
\end{tabular}

density crops in 1991/1992. During the growing season, $A 1$ and $A 2$ never intercepted $90 \%$ of incident radiation (fig 2). As a consequence, the AO was never totally shaded. The duration of the period during which LAI of the whole plant exceeded 2.5 varied between 0 and $652^{\circ} \mathrm{C} \cdot \mathrm{d}$, although it varied between 797 and $1128^{\circ} \mathrm{C} \cdot \mathrm{d}$ on Lunoble. The duration of LAl above $2.5(y)$ was related to the maximum total dry matter $(x)$ for the 2 growth habits (fig 3 ), but the regression lines were very different $(y=273+0.46 x$ for Lunoble, $r=0.90, P<0.001 ; y=-1420+1.58 x$ for determinates, $r=0.88, P<0.001$ ).

\section{Pod growth}

Pod growth followed sigmoid curves (fig 4). Expressed in ${ }^{\circ} \mathrm{C} \cdot \mathrm{d}$ from sowing, pod growth started earlier for late sowing than for early sowing. Indeed late-sown plants had less mainstem leaves to expand before flowering and pod set. In 1990/ 1991, final pod dry matter was affected by neither sowing date nor density. But in 1991/

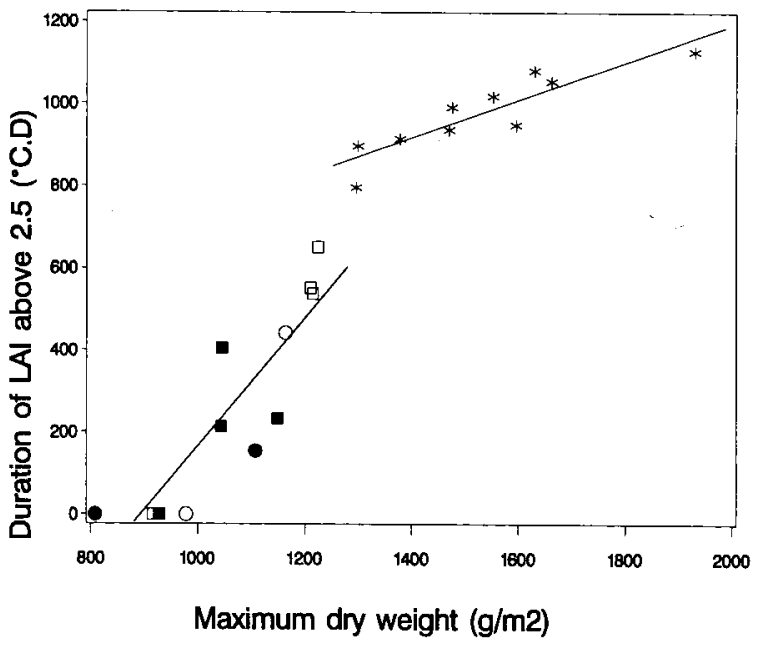

Fig 3. Maximum dry weight as influenced by duration of LAI above 2.5 for 2 determinate genotypes ( $\square, \mathrm{\square}: \mathrm{CH} 304 / 70$ and O, $\mathrm{CH} 304 / 73$ ) in $1990 / 1991$ and $1991 / 1992$, sown at 2

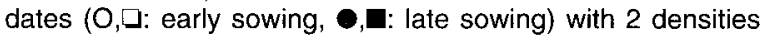
and for 2 indeterminate cultivar ( ${ }^{*}$ : Lunoble) during 4 seasons and 2 or 3 densities.

1992, it decreased for late sowing and low density (table II). On the determinate lines, pod growth became significant when the vegetative growth (stems and leaves) was finished (fig 5). On the contrary, on Lunoble, the pod growth was concomitant with the vegetative growth.

For the conditions studied, pod growth rate was significantly lower at low density but was not affected by sowing date (table II). Pods on AO represented the largest part of total pods especially at high density (fig 4). Pod weights on A1 were similar at low and high densities in 1991/ 1992, but were significantly higher in 1990/1991 at low density than at high density. Pods on A2 and basal branches always represented a negligible proportion of the total pods. Pod growth rate was higher on determinates $\left(1.02 \mathrm{~g}^{-2} \mathrm{~m}^{-2}\right.$. $\left.{ }^{\circ} \mathrm{C}^{-1} \bullet \mathrm{d}^{-1}\right)$ than on Lunoble $\left(0.81 \mathrm{~g} \cdot \mathrm{m}^{-2 \cdot{ }^{\circ}} \mathrm{C}^{-1} \cdot \mathrm{d}^{-1}\right)$. The reduction of vegetative development in determinates could explain this better feeding of growing pods. This feature has also been observed by Milford et al (1993a) for the growth in length of the individual pods.

\section{Root/stem ratio}

Plotting tap-root dry matter $(x)$ against dry matter of stems ( $y$. mainstem and branches) showed an allometric relationship $\left(y=1.128 x^{1.344}, r=0.99\right.$, $P<0.001$, fig 6 ). All genotypes including Lunoble, sowing dates, densities and growth stages 


\section{CH304/70}

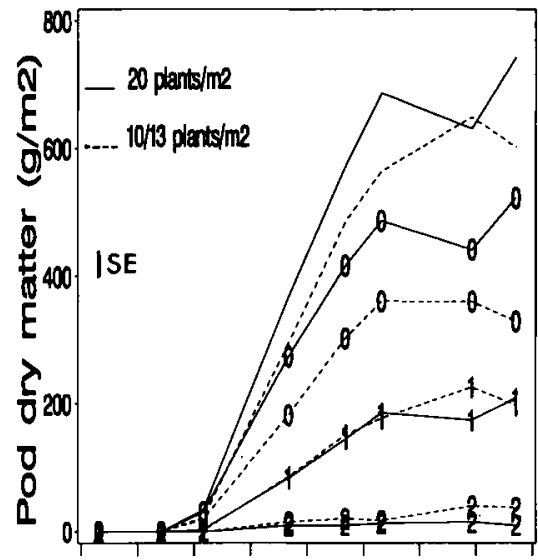

$\begin{array}{lllllll}8000001200 & 1400 \quad 1000 \quad 1800 \quad 2000 & 2200 & 2400\end{array}$

Thermal time from sowing ('C.D)

\section{CH304/73}

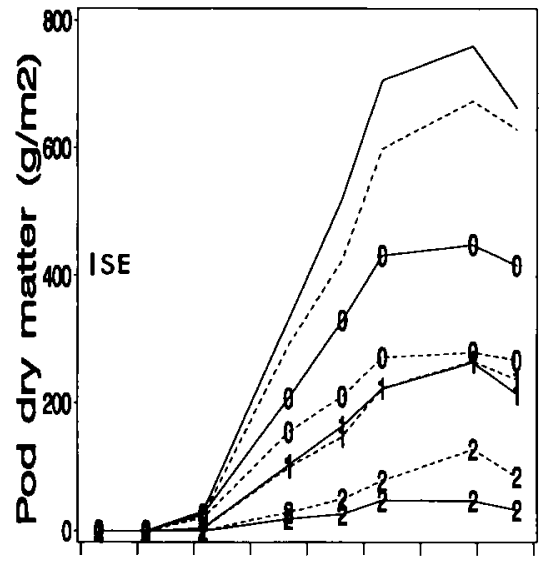

$0001000 \quad 200014001600110002000 \quad 22002400$

Thermal time from sowing ( $C . D$ )

Fig 4. Pod dry weight per level (0: A0; 1: A1; 2: A2) and total pod dry weight (lines without symbols) for 2 determinate genotypes ( $\mathrm{CH} 304 / 70$ and $\mathrm{CH} 304 / 73)$ in 1991/1992, sown on 05/10 with 2 densities. SE are for the total pod curves.

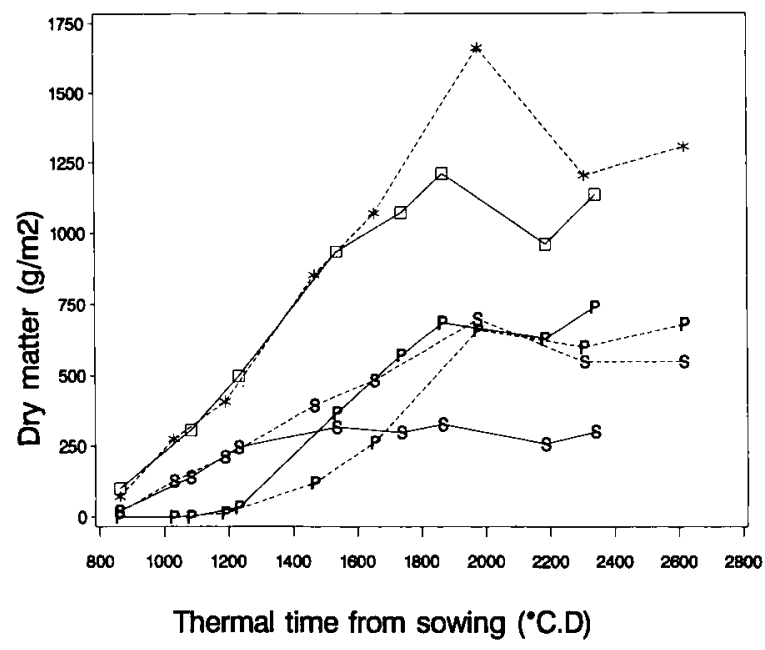

Fig 5. Overall $(\square, ;)$, pod $(P)$, and stem $(S)$ growth during the growing season on $\mathrm{CH} 304 / 70$ (--- ---$)$ and Lunoble (---*---) sown on $05 / 10 / 1991$ at 20 plants $/ \mathrm{m}^{2}$.

fitted this general relationship. The development of the tap-root followed exactly that of all the stems, during all the growing season, and represented between 4 and $16 \%$ of the total weight and about $21 \%$ of the stem dry weight. The allometric relationship found between root and stem weights is very common in the vegetable kingdom (France and Thornley, 1984). This relationship shows that the modification of the architecture of the branches by the introduction of the

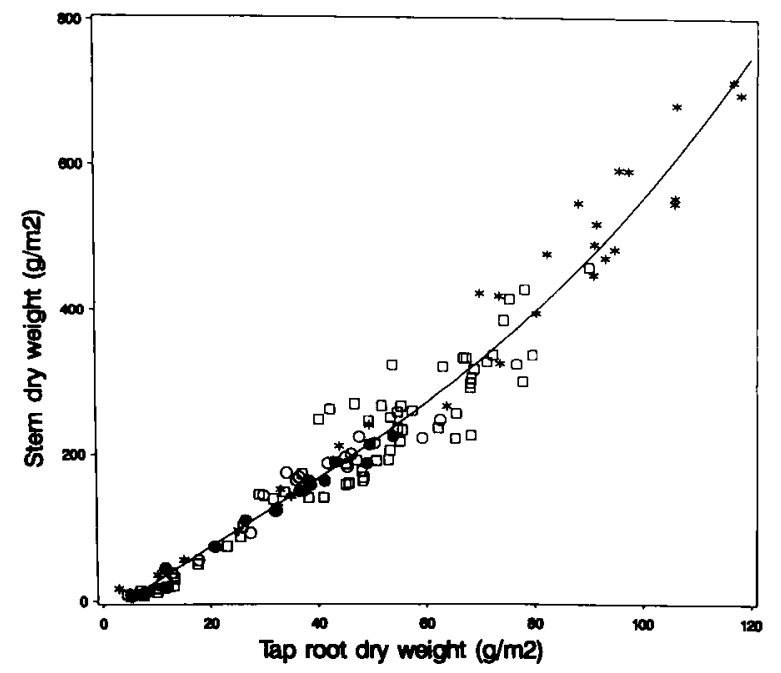

Fig 6. Relationship between tap-root dry weight and stem dry weight for 2 determinate genotypes ( $0, \mathbf{m}$ : $\mathrm{CH} 304.70$ and O,e: $\mathrm{CH} 304 / 73$ ) in 1990/1991 and 1991/1992, sown at 2 dates $(0, \square$ : early sowing, 0,1 : late sowing) with 2 densities and for 1 indeterminate cultivar ( $*$ : Lunoble) sown at the early date with 2 densities. Eight samplings were made during the growing season.

determinate trait induced a reduction of the taproot, but did not change the relationship between the root and the stems. No data is available on whether the volume of the tap-root is related to the volume of soil prospected by the rootlets. Passioura (1983) argued that the root system of many crops may be unnecessarily 
large and that, if it was smaller, more assimilate could be available for the shoot and grain production. In this context, the reduction of tap-root dry weight in determinate lupin might not be a problem for the plant nutrition and growth. Charles-Edwards (1982) stated that the growth of roots or stems depends on their activities. He suggested that the root and stem activities were proportional. This could explain their parallel development.

\section{Nitrogen accumulation}

Nitrogen $(\mathrm{N})$ accumulation in the plants during the growth period was parallel to total dry matter accumulation (data not shown). At maturity, the mean total $\mathrm{N}$ amount was $23.8 \mathrm{~g} / \mathrm{m}^{2} ; 95 \%$ of this was in pods (table IV) and the rest was in the stems and tap-root. $\mathrm{N}$ amount was lower at the late sowing date and low density. Total accumulated $\mathrm{N}$ was lower than for Lunoble $\left(30.4 \mathrm{~g} / \mathrm{m}^{2}\right.$, Julier et al, 1993a) as a consequence of lower total dry matter. The mean $\mathrm{N}$ content of the plant was on average $2.8 \%$ with variation during the growing season (fig 7). The leaves had on average $4.5 \% \mathrm{~N}$. The $\mathrm{N}$ content of the leaves was maximum at $1500^{\circ} \mathrm{C} \cdot \mathrm{d}$ after sowing and decreased during the senescence of the leaves. The root and stems had $1.6 \%$ of $\mathrm{N}$ in early spring and this content decreased to less than $0.5 \%$ at maturity. The pods had a constant $\mathrm{N}$ content, $3.8 \%$, throughout the growing season.

\section{Seed yield and mean seed weight (experiments 1 and 2)}

\section{Total seed yield}

In both experiments, mean seed yields were similar (3.68 and 3.63 t/ha in experiments 1 and 2 respectively, least significant difference (LSD) = 0.253 ). Significantly higher yields were obtained in early sowing and at high plant density (table V). $\mathrm{CH} 304 / 70$ and $\mathrm{CH} 304 / 73$ yields were significantly different, on average 3.47 and 3.89 tha respectively (LSD $=0.251$ ). Distribution of yield on the plant levels was significantly affected by genotype and density, but not by sowing date. Yield on AO increased with the density and was more significant for $\mathrm{CH} 304 / 70$ than for $\mathrm{CH} 304$ / 73. It averaged $70 \%$ of the total yield. In con-

Table IV. Nitrogen yield $\left(\mathrm{g} / \mathrm{m}^{2}\right)$ at maturity for 2 determinate genotypes $(\mathrm{CH} 304 / 70$ and $\mathrm{CH} 304 / 73)$ grown at Lusignan, at 2 sowing dates and 2 densities in 1990/1991 and 1991/1992.

\begin{tabular}{|c|c|c|c|c|c|c|c|}
\hline \multirow[t]{2}{*}{ Sowing date } & \multirow[t]{2}{*}{ Plant density } & \multirow[t]{2}{*}{ Tap-root } & \multirow[t]{2}{*}{ Stems } & \multicolumn{2}{|c|}{ Pods } & \multirow[t]{2}{*}{ Total } & \multirow[t]{2}{*}{ N Harvest index } \\
\hline & & & & Walls & Seeds & & \\
\hline \multicolumn{8}{|c|}{$1990 / 1991 \mathrm{CH} 304 / 70$} \\
\hline $05 / 10$ & 13 & 0.43 & 1.49 & 1.53 & 20.30 & 23.75 & 0.855 \\
\hline $05 / 10$ & 20 & 0.50 & 2.12 & 1.61 & 20.26 & 24.49 & 0.827 \\
\hline $22 / 10$ & 13 & 0.36 & 1.44 & 2.17 & 21.11 & 25.03 & 0.843 \\
\hline $22 / 10$ & 20 & 0.33 & 1.25 & 1.60 & 19.38 & 22.55 & 0.859 \\
\hline \multicolumn{8}{|c|}{ 1991/1992 CH304/70 } \\
\hline $05 / 10$ & 10 & 0.18 & 0.92 & 4.37 & 17.77 & 23.16 & 0.767 \\
\hline $05 / 10$ & 20 & 0.27 & 1.25 & 3.90 & 26.10 & 31.57 & 0.827 \\
\hline $25 / 10$ & 10 & 0.16 & 0.75 & 2.69 & 15.78 & 19.38 & 0.814 \\
\hline $25 / 10$ & 20 & 0.20 & 0.79 & 3.18 & 19.08 & 23.25 & 0.821 \\
\hline \multicolumn{8}{|c|}{ 1991/1992 CH304/73 } \\
\hline $05 / 10$ & 10 & 0.13 & 0.72 & 4.20 & 17.92 & 22.92 & 0.781 \\
\hline $05 / 10$ & 20 & 0.16 & 0.88 & 3.46 & 22.43 & 26.94 & 0.833 \\
\hline $25 / 10$ & 10 & 0.13 & 0.51 & 3.13 & 12.94 & 16.66 & 0.777 \\
\hline $25 / 10$ & 20 & 0.15 & 0.67 & 3.48 & 20.94 & 25.25 & 0.829 \\
\hline \multicolumn{2}{|c|}{ Mean } & 0.25 & 1.07 & 2.94 & & 23.75 & 0.820 \\
\hline \multicolumn{2}{|c|}{ LSD genotype and year } & 0.058 & 0.258 & 0.739 & 3.974 & 4.354 & 0.0309 \\
\hline \multicolumn{2}{|c|}{ LSD sowing date and density } & 0.055 & 0.243 & 0.697 & 3.747 & 4.105 & 0.0292 \\
\hline
\end{tabular}


$\mathrm{CH} 30470$

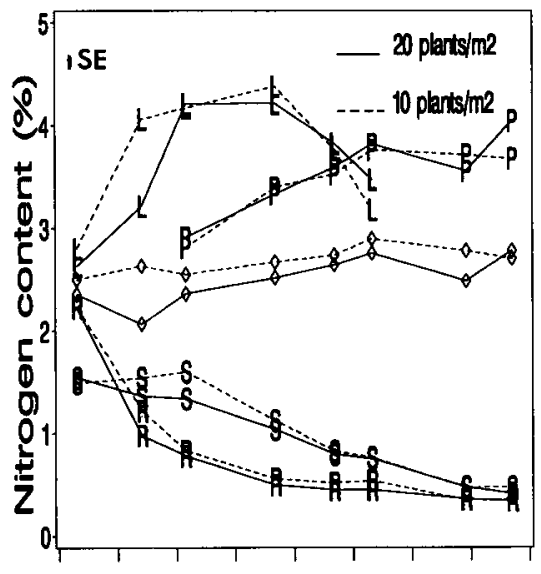

$800 \quad 1000 \quad 1200 \quad 1400 \quad 1600 \quad 1800 \quad 2000 \quad 20002400$

\section{Thermal time from sowing ( $\mathrm{C} . \mathrm{C})$}

\section{$\mathrm{CH} 30473$}

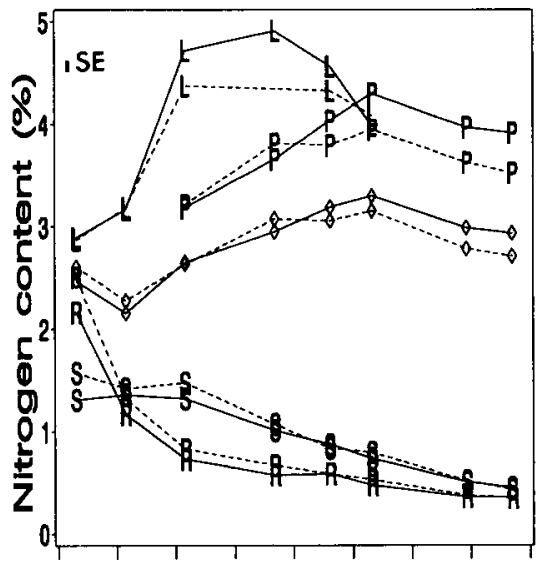

$800 \quad 1000 \quad 1200 \quad 1400 \quad 1600 \quad 1800 \quad 2000 \quad 2200 \quad 2400$

Thermal time from sowing ('C.D)

Fig 7. Nitrogen content in the different organs (P: pods; L: leaves; S: stems; R: tap-root; $৩$ : overall) during the growing season, for 2 determinate genotypes (CH304/70 and $\mathrm{CH} 304 / 73$ ) in 1991/1992, sown on 05/10 with 2 densities. SE are for the overall nitrogen curves.

trast, yield on $A 1$ increased at low density but its contribution to total yield only averaged $26 \%$. A2 only yielded on $\mathrm{CH} 304 / 73$ in the irrigated experiment 1 . Basal branches only contributed to total yield in early sowings at low density. Despite covering a wide range of husbandry techniques and environmental conditions, the seed yield proved to be stable. The standard deviations of the means were $0.37 \mathrm{t} / \mathrm{ha}$ for $\mathrm{CH} 304 / 70$ and $0.66 \mathrm{t}$ ha for $\mathrm{CH} 304 / 73$. This stability was achieved through compensation between levels. In Lunoble, where the average yield was higher $(4.09 \mathrm{t} /$ ha), such a stability was not observed, and the standard deviation of the mean was $0.87 \mathrm{t} / \mathrm{ha}$ in the experiments described by Huyghe et al (1993). Indeed, in 1991/1992, the determinates yielded similarly with or without irrigation while Lunoble yield was negatively affected by irrigation because of an excessive vegetative development. In contrast, the irrigation did not change the vegetative development of the determinates. This better stability of both determinate genotypes confirms the results of Julier et al (1993b).

\section{Mean seed weight}

Mean seed weight was significantly affected by experiment, genotype, sowing date and plant density (table V). Mean seed weight was higher in the unirrigated experiment 2 than in experiment 1 (288 and $269 \mathrm{mg}$ respectively, LSD =
9.1), for $\mathrm{CH} 304 / 70$ than for $\mathrm{CH} 304 / 73$ (295 and $261 \mathrm{mg}, \mathrm{LSD}=9.0)$ and in late sowing $(267,279$ and $289 \mathrm{mg}$ for the first, second and third sowings respectively, $L S D=11.5$ ). Mean seed weights were similar on $A 0$ and $A 1$ (280 versus $274 \mathrm{mg}$ ). When available, mean seed weight on A2 and on basal branches appeared very small.

Yield was highly correlated with seed number per $\mathrm{m}^{2}(r=0.84, P<0.001)$, but was independent of mean seed weight $(r=-0.15, P>0.05)$. The same trends were observed for each level. As seed number per pod is a very stable component (Withers, 1984), this showed that pod setting was the main limiting factor for higher yield on determinates. Flower production was important on each inflorescence, and the percentage of flower abscission was large, as on indeterminates; about $80 \%$ of the flowers did not produce a mature pod (unpublished data). However, the fact that pod setting was almost synchronous on the mainstem and the branches could induce a lack of assimilates available for pod growth at a given moment of the season, and then induce early pod or seed abortions. But seed filling was not limited. Indeed, during seed filling, vegetative growth stopped, and so assimilates produced were available for reproductive growth. On Lunoble, yield was related to both seed number per $\mathrm{m}^{2}$ and mean seed weight (Huyghe et al, 1993). In indeterminate plants, seed filling and vegetative growth occur at the same time, 
Table V. Yield ( $t / \mathrm{ha})$, mean seed weight $(\mathrm{mg})$ per level and harvest index for 2 determinate genotypes (CH304/70 and $\mathrm{CH} 304 / 73$ ) grown at Lusignan, at 2 sowing dates and 2 plant densities in 1990/1991 and 1991/1992 (experiment 1) and at 3 sowing dates and 3 densities in 1991/1992 (experiment 2).

\begin{tabular}{|c|c|c|c|c|c|c|c|c|c|c|c|c|}
\hline \multirow{2}{*}{\multicolumn{2}{|c|}{ Sowing date Plant density }} & \multicolumn{5}{|c|}{ Yield } & \multicolumn{5}{|c|}{ Mean seed weight } & \multirow[t]{2}{*}{ Harvest ir } \\
\hline & & Total & Basal & $A O$ & $A 1$ & $A 2$ & Total & Basal & $A O$ & $A 1$ & $A 2$ & \\
\hline \multicolumn{13}{|c|}{$\begin{array}{l}\text { Experiment } 1 \\
1990 / 1991 \mathrm{CH} 304 / 70\end{array}$} \\
\hline $05 / 10$ & 13 & 3.50 & 0 & 2.58 & 0.92 & 0 & 306 & - & 307 & 306 & - & 0.38 \\
\hline $05 / 10$ & 20 & 3.39 & 0 & 2.92 & 0.47 & 0 & 322 & - & 323 & 314 & - & 0.35 \\
\hline $22 / 10$ & 13 & 3.62 & 0 & 2.25 & 1.34 & 0.03 & 284 & - & 284 & 283 & - & 0.40 \\
\hline $22 / 10$ & 20 & 3.44 & 0 & 2.57 & 0.86 & 0 & 300 & - & 304 & 287 & - & 0.40 \\
\hline \multicolumn{13}{|c|}{ 1991/1992 CH304/70 } \\
\hline $05 / 10$ & 10 & 3.56 & 0.22 & 1.97 & 1.17 & 0.20 & 265 & - & 267 & 262 & - & 0.46 \\
\hline $05 / 10$ & 20 & 4.67 & 0.01 & 3.21 & 1.40 & 0.05 & 274 & - & 279 & 263 & - & 0.44 \\
\hline $25 / 10$ & 10 & 3.02 & 0.01 & 1.61 & 1.33 & 0.06 & 245 & - & 250 & 240 & - & 0.47 \\
\hline $25 / 10$ & 20 & 3.59 & 0 & 2.50 & 1.07 & 0.02 & 293 & - & 300 & 272 & - & 0.48 \\
\hline \multicolumn{13}{|c|}{ 1991/1992 CH304/73 } \\
\hline $05 / 10$ & 10 & 3.92 & 0.25 & 1.71 & 1.48 & 0.47 & 230 & - & 224 & 237 & - & 0.51 \\
\hline $05 / 10$ & 20 & 4.19 & 0 & 2.73 & 1.29 & 0.18 & 247 & - & 246 & 247 & - & 0.50 \\
\hline $25 / 10$ & 10 & 2.85 & 0.09 & 1.42 & 1.10 & 0.25 & 208 & - & 213 & 201 & - & 0.51 \\
\hline $25 / 10$ & 20 & 4.36 & 0.02 & 2.61 & 1.53 & 0.20 & 248 & - & 252 & 241 & - & 0.54 \\
\hline
\end{tabular}

\begin{tabular}{|c|c|c|c|c|c|c|c|c|c|c|c|c|}
\hline Experiment 2 & & & & & & & & & & & & \\
\hline $18 / 09$ & 10 & 3.22 & 0.24 & 2.31 & 0.67 & 0.01 & 287 & 258 & 289 & 288 & 255 & 0.37 \\
\hline $18 / 09$ & 20 & 3.39 & 0.05 & 2.81 & 0.51 & 0.01 & 267 & 228 & 272 & 246 & 245 & 0.32 \\
\hline $18 / 09$ & 40 & 3.23 & 0 & 3.03 & 0.19 & 0 & 277 & - & 276 & 297 & - & 0.28 \\
\hline $05 / 10$ & 10 & 3.30 & 0.06 & 2.41 & 0.83 & 0 & 309 & 276 & 307 & 317 & 233 & 0.50 \\
\hline $05 / 10$ & 20 & 3.48 & 0 & 3.02 & 0.45 & 0 & 301 & - & 305 & 274 & - & 0.45 \\
\hline $05 / 10$ & 40 & 3.32 & 0 & 3.29 & 0.03 & 0 & 283 & - & 283 & 262 & - & 0.38 \\
\hline $25 / 10$ & 10 & 3.07 & 0 & 1.89 & 1.16 & 0.01 & 302 & 150 & 306 & 298 & 151 & 0.52 \\
\hline $25 / 10$ & 20 & 3.31 & 0 & 2.78 & 0.51 & 0.02 & 350 & - & 352 & 338 & 336 & 0.53 \\
\hline $25 / 10$ & 40 & 3.88 & 0 & 3.72 & 0.17 & 0 & 347 & - & 347 & 341 & - & 0.47 \\
\hline \multicolumn{13}{|l|}{$\mathrm{CH} 304 / 73$} \\
\hline $18 / 09$ & 10 & 4.61 & 0.88 & 2.07 & 1.66 & 0 & 259 & 259 & 267 & 248 & - & 0.45 \\
\hline $18 / 09$ & 20 & 4.65 & 0.35 & 2.42 & 1.88 & 0 & 266 & 264 & 271 & 260 & - & 0.40 \\
\hline $18 / 09$ & 40 & 4.40 & 0.12 & 2.91 & 1.37 & 0 & 246 & 215 & 255 & 230 & - & 0.40 \\
\hline $05 / 10$ & 10 & 3.41 & 0.13 & 1.91 & 1.34 & 0.03 & 272 & 267 & 267 & 284 & 237 & 0.57 \\
\hline $05 / 10$ & 20 & 3.67 & 0.03 & 2.79 & 0.85 & 0 & 257 & 239 & 260 & 245 & - & 0.53 \\
\hline $05 / 10$ & 40 & 4.11 & 0 & 3.64 & 0.47 & 0 & 280 & - & 283 & 255 & - & 0.48 \\
\hline $25 / 10$ & 10 & 2.71 & 0.10 & 1.60 & 0.95 & 0.06 & 278 & 241 & 283 & 277 & 242 & 0.56 \\
\hline $25 / 10$ & 20 & 3.19 & 0 & 2.34 & 0.85 & 0 & 304 & - & 307 & 297 & 214 & 0.57 \\
\hline $25 / 10$ & 40 & 4.46 & 0 & 3.71 & 0.73 & 0.01 & 308 & - & 312 & 289 & - & 0.52 \\
\hline Mean & & 3.65 & 0.09 & 2.56 & 0.95 & 0.05 & 281 & 244 & 283 & 274 & 231 & 0.46 \\
\hline LSD genotype & & 0.251 & 0.06 & 0.15 & 0.14 & 0.03 & 9.1 & 26.6 & 9.0 & 11.1 & 10.9 & 0.012 \\
\hline LSD experiment & & 0.253 & 0.06 & 0.15 & 0.14 & 0.03 & 9.2 & - & 9.1 & 11.2 & - & 0.012 \\
\hline LSD date & & 0.321 & 0.07 & 0.19 & 0.18 & 0.04 & 11.6 & 37.0 & 11.5 & 14.2 & 14.7 & 0.016 \\
\hline LSD density & & 0.321 & 0.07 & 0.19 & 0.18 & 0.04 & 11.6 & 41.5 & 11.5 & 14.2 & 12.2 & 0.016 \\
\hline
\end{tabular}


so available assimilates were shared between these 2 sinks.

\section{Nitrogen content}

$\mathrm{N}$ seed yield averaged $19.50 \mathrm{~g} / \mathrm{m}^{2}$ (table IV), and the $\mathrm{N}$ content of the seeds was $5.4 \%$. In the pods at maturity, pod walls stored $13 \%$ of $N$, most of the $\mathrm{N}$ stored here during the pod growth had been remobilized towards the seeds. $\mathrm{N}$ content of the seeds were similar to that of Lunoble, showing no deleterious effect of reduction of vegetative vigour on seed quality. Nitrogen harvest index ( $\mathrm{N}$ seed yield divided by total above-ground $\mathrm{N})$ varied between 0.78 and 0.86 , and averaged 0.82 (table V). Similar $N$ harvest indices of 0.88 and between 0.80 and 0.91 were reported by Duthion et al (1987) and Larson et al (1989), respectively.

\section{Relationship between yield and plant structure}

Relationships between yield and vegetative development were assessed. Yield on $\mathrm{AO}(y)$ was non-linearly linked to number of mainstem leaves per $\mathrm{m}^{2}(x)$ (fig 8). The curve equation was: $y=$ $0.885+4.587 \times 10^{-3} \times-2.034 \times 10^{-6} x^{2}(r=0.89$, $P<0.001)$. The maximum yield on A0 was obtained for 1134 mainstem leaves per $\mathrm{m}^{2}$, and was 3.5 tha. It can be reached by early sowing (leading to numerous leaves on the mainstem) and high density. An excess of mainstem leaves per $\mathrm{m}^{2}$ was detrimental to $\mathrm{AO}$ yield. In the condi-

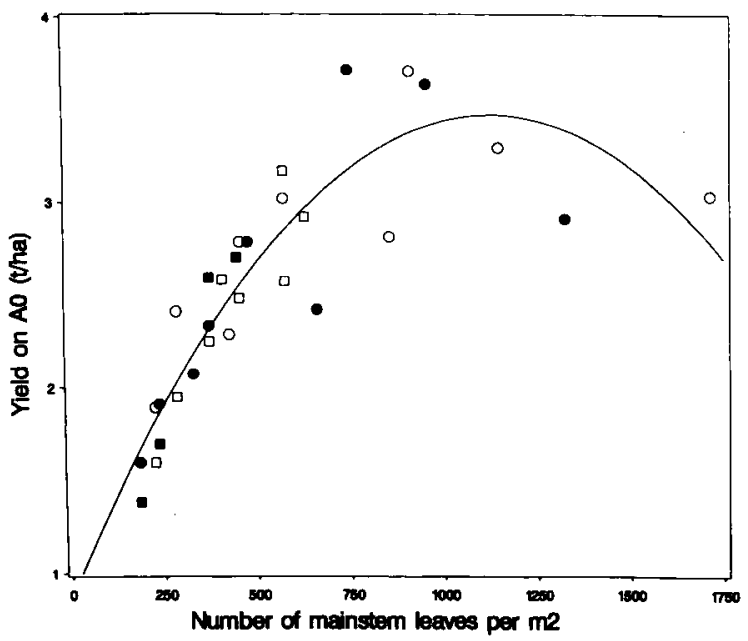

Fig 8. Yield on $A O$ as influenced by the number of mainstem leaves by unit area, for 2 determinate genotypes $(O, \square$ : $\mathrm{CH} 304 / 70$ and, $\mathrm{CH}$ : $\mathrm{CH} 04 / 73$ ), in 1990/1991 and 1991/ 1992, in experiment $1(\square, \square)$ and experiment $2(O, O)$ tions experienced at Lusignan, plants sown early at high density lodged, which induced bad pod setting and seed filling. Yield on A1 was not correlated with the number of $A 1$ leaves per $\mathrm{m}^{2}$ $(r=-0.27, P>0.05)$. Yields on $A 0$ and $A 1$ were negatively correlated $(r=-0.58, P<0.001)$. As the first-order branches of the determinates bear few leaves (Julier and Huyghe, 1993), the delay between flowering of the mainstem and of these branches is short. Consequently, the seed filling of the pods of these 2 levels occurs almost simultaneously. The mainstem pods and the branch pods formed a unique sink (Milford et al, 1993a); they shared the same pool of assimilates. This explains the negative relationship between the yields on $A 0$ and $A 1$ and the compensation between pod levels for the total seed yield. Total yield could not be directly predicted by any of the morphological characters studied and may not be obtained with the conditions maximizing yield on $\mathrm{AO}$. On Lunoble (Huyghe et al, 1993; Julier et al, 1993a) and on indeterminate spring-sown genotypes (Porter, 1982; Pigeaire et al, 1992), yield on A0 was negatively correlated with upper branch development, but this feature was not observed on determinates.

Harvest index $(\mathrm{HI})$, calculated as seed yield divided by total above-ground dry matter at maturity (table V), varied between 0.28 and 0.57 . In $1991 / 1992$, for the same sowing dates $(05 / 10$ and 25/10) and the same densities (10 and 20 plant $/ \mathrm{m}^{2}$ ), HI was significantly higher in the unirrigated experiment 2 than in the irrigated experiment $1(0.52$ and 0.45 , respectively, LSD $=$ $0.012)$. $\mathrm{HI}$ was influenced by genotype $(0.42$ for $\mathrm{CH} 304 / 70,0.50$ for $\mathrm{CH} 304 / 73$, $\mathrm{LSD}=0.012$ ), sowing date (delaying sowing increased $\mathrm{HI}$ ), and density ( $\mathrm{HI}$ increased at lower density). Yield was not correlated with $\mathrm{HI}(r=-0.03, P>$ 0.05 ), but was correlated with total aboveground dry matter $(r=0.61, P<0.001)$. However, $\mathrm{HI}$ and total above-ground dry matter were negatively correlated $(r=-0.76, P<0.001)$. $\mathrm{HI}$ was higher on determinates than on Lunoble $(0.46$ versus 0.41$)$. In the determinates, the lower within-plant competition between vegetative and reproductive growth during the growing season could explain a more efficient partitioning of the dry matter into pods.

This study has shown that the modification of plant architecture leads to a modification of the accumulation and partitioning of dry matter during all the growing season. The determinate architecture induces the reduction of dry matter production, and causes the reproductive growth 
to be almost entirely separated from the vegetative growth so within-plant competition was lessened.

\section{ACKNOWLEDGMENT}

We thank UNIP (Union Nationale Interprofessionelle des plantes riches en Protéines) for financial support.

\section{REFERENCES}

Bernard RL (1972) Two genes affecting stem termination in soybean. Crop Sci 12, 235-239

Charles-Edwards DA (1982) Physiological Determinants of Crop Growth. Academic Press, Sydney

Duthion C, Amarger N, Mariotti A (1987) Accumulation potentielle de matière sèche et d'azote chez le lupin blanc de printemps (Lupinus albus L). agronomie 7, 585-593

Farrington P, Greenwood EAN (1975) Description and specification of the branching structure of lupins. Aust J Agric Res 26, 507-510

France J, Thornley JHM (1984) Mathematical Models in Agriculture. Butterworths, London

Huyghe $C$ (1990) White lupin architecture, genetic variability, agronomic consequences. Proc 6 th Int $\mathrm{Lu}$ pin Conf (D von Baer, ed), International Lupin Association, Temuco-Pucon, 241-254

Huyghe C (1991) Winter growth of autumn-sown white lupin (Lupinus albus L): main apex growth model. Ann Bot 67, 429-434

Huyghe C (1992) Le lupin. In: Amélioration des espèces végétales cultivées, objectifs et critères de sélection (A Gallais, R Bannerot, eds) Paris, 204217

Huyghe C, Julier B, Papineau J, Harzic N (1993) Yield and yield components on autumn-sown white lupin cv Lunoble. Eur J Agron (in press)

Julier B, Huyghe C (1992) Heredity of determinate growth in winter white lupin. Influence of the sowing time on architecture. Proc 1st Eur Conf on Grain Legume. Angers, 47-48

Julier B, Huyghe C (1993) Description and model of the architecture of four genotypes of determinate autumn-sown white lupin (Lupinus albus $\mathrm{L}$ ) as influenced by location, sowing date and density. Ann Bot 72, 493-501

Julier B, Huyghe C, Papineau J (1993a) Dry matter and nitrogen accumulation on autumn-sown white lupin cv Lunoble. Eur J Agron (in press)

Julier B, Huyghe C, Papineau J, Milford GFJ, Day JM, Billot C, Mangin P (1993) Yield and yield stability of determinate and indeterminate autumn-sown white lupins (Lupinus albus $\mathrm{L}$ ) at different locations in France and the UK. J Agric Sci, Cambridge 121, 177-186

Larson KJ, Cassman KG, Phillips DA (1989) Yield, dinitrogen fixation and above-ground nitrogen balance of irrigated lupin in a Mediterranean climate. Agron J 81, 538-543

Mikolajczyk J, Stawinsky S, Wiza M (1984) Directions actuelles de l'amélioration et l'état actuel des recherches sur l'acclimatation du lupin blanc en Pologne. Proc 3rd Int Lupin Conf International Lupin Association, La Rochelle, 570-571

Milford GFJ, Day JM, Huyghe C, Julier B (1993a) Floral determinacy in autumn-sown white lupins (Lupinus albus): the development of varieties for cooler European climates. Aspects Appl Biol, Physiology of Varieties 34, 89-97

Milford GFJ, Day JM, Leach JE, Stevenson HJ, Huyghe C, Papineau J (1993b) The effect of modifying plant structure on the yield and maturity of the white lupin Lupinus albus. Ann Appl Biol 122, 113122

Passioura JB (1983) Root and drought resistance. Agric Water Manage 7, 265-280

Pigeaire A, Seymor M, Delane R, Atkins CA (1992) Partitioning of dry matter into primary branches and pod initiation on the main inflorescence of Lupinus angustifolius. Aust J Agric Res 43, 685-696

Porter NG (1982) Interaction between lateral branch growth and pod set in primary inflorescences of lupin. Aust J Agric Res 33, 957-965

Sjödin J (1971) Induced morphological variation in Vicia faba L. Hereditas 67, 155-180

Snoad B (1974) A preliminary assessment of "leafless" peas. Euphytica 23, 257-265

Withers NJ (1984) Components of lupin seed yield. Proc 3rd Int Lupin Conf International Lupin Association, La Rochelle, 270-287 